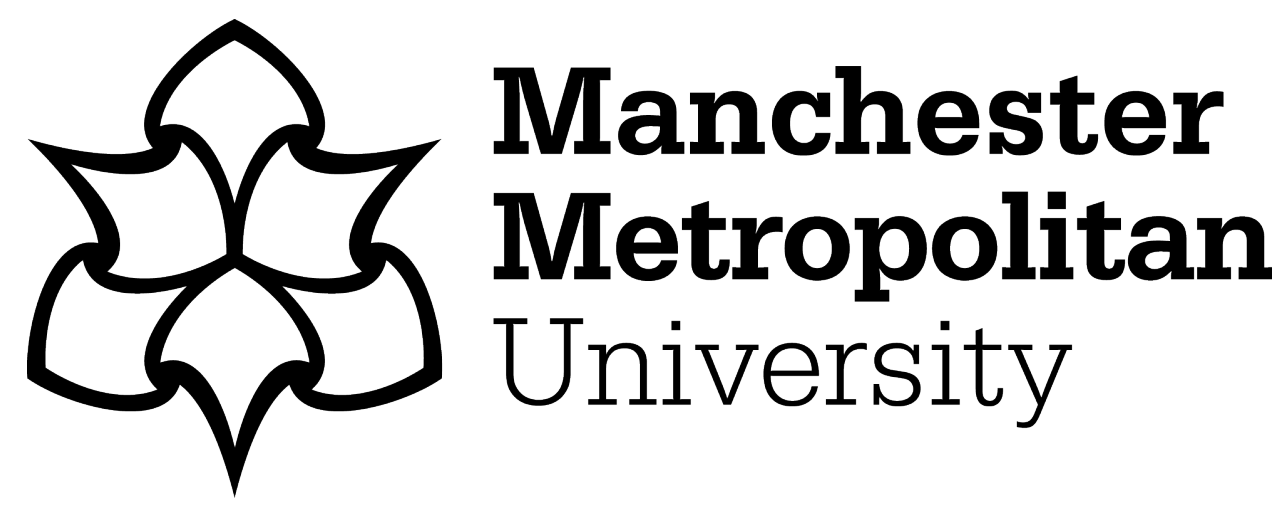

MacDonald, M ORCID logoORCID: https://orcid.org/0000-0001-9115-9065 and Howorth, C (2018) Roots of social enterprise: entrepreneurial philanthropy, England 1600-1908. Social Enterprise Journal, 14 (1). pp. 4-21. ISSN 1750-8614

Downloaded from: https://e-space.mmu.ac.uk/624738/

Version: Accepted Version

Publisher: Emerald

DOI: https://doi.org/10.1108/SEJ-03-2017-0020

Please cite the published version 


\section{UNIVERSITY oflfork}

This is a repository copy of Roots of Social Enterprise : Entrepreneurial Philanthropy, England 1600-1908.

White Rose Research Online URL for this paper:

http://eprints.whiterose.ac.uk/125978/

Version: Accepted Version

\section{Article:}

MacDonald, Matthew and Howorth, Carole orcid.org/0000-0002-5547-687X (2018) Roots of Social Enterprise : Entrepreneurial Philanthropy, England 1600-1908. Social Enterprise Journal. pp. 4-21. ISSN 1750-8614

https://doi.org/10.1108/SEJ-03-2017-0020

\section{Reuse}

Items deposited in White Rose Research Online are protected by copyright, with all rights reserved unless indicated otherwise. They may be downloaded and/or printed for private study, or other acts as permitted by national copyright laws. The publisher or other rights holders may allow further reproduction and re-use of the full text version. This is indicated by the licence information on the White Rose Research Online record for the item.

\section{Takedown}

If you consider content in White Rose Research Online to be in breach of UK law, please notify us by emailing eprints@whiterose.ac.uk including the URL of the record and the reason for the withdrawal request. 


\section{Roots of Social Enterprise: Entrepreneurial Philanthropy, England 1600-1908}

\begin{tabular}{|r|l|}
\hline Journal: & Social Enterprise Journal \\
\hline Manuscript ID & SEJ-03-2017-0020.R1 \\
\hline Manuscript Type: & Research Paper \\
\hline Keywords: & $\begin{array}{l}\text { Social enterprise, history, review, welfare provision, poverty relief, } \\
\text { entrepreneurship }\end{array}$ \\
\hline \multicolumn{2}{|l}{} \\
\hline
\end{tabular}

SCHOLARONE $^{\text {tm }}$

Manuscripts 


\title{
Roots of Social Enterprise: Entrepreneurial Philanthropy, England 1600-1908
}

\author{
Abstract \\ Purpose: Insights into the roots of social enterprise from before the term was adopted are \\ provided by examining histories of charitable service and comparing current \\ understandings of social enterprise. Social enterprise models of welfare provision are \\ evidenced from the $17^{\text {th }}$ Century onwards. Persistent themes are identified that provide \\ insights for current practice and understanding. \\ Design/Methodology/Approach: This historiography examines interpretations from 1905 \\ to the present day of examples of welfare provision between two watershed points: 1600, \\ just prior to the Poor Laws and 1908, when the Old Age Pensions Act shifted emphasis in \\ public sector provision. \\ Findings: Activities that would nowadays be termed social enterprise are evidenced in \\ histories of charitable philanthropy covering each Century since 1600. Prevailing \\ attitudes uncritically demarcated deserving and undeserving poor. Histories contributed \\ to a heroic narrative of social entrepreneurs, describing activities dependent on well- \\ networked, politically active individuals that rarely continued beyond their involvement. \\ The political environment was recognised to influence the types of organisations, \\ governance and resourcing. \\ Research limitations/Implications: The historiography takes examples from three \\ centuries between 1600 and1908 but is not comprehensive. Recurrent themes are \\ identified for further research.
}


Originality/Value: Social enterprise is a $21^{\text {st }}$ Century label but not a new phenomenon. Identification of prevailing themes provides insights for the understanding of social enterprises in the $21^{\text {st }}$ Century.

Type of Paper: Research Paper

Keywords: social enterprise; history; review;

\section{Introduction}

Social enterprise is sometimes discussed as a new phenomenon which arose around the turn of the $21^{\text {st }}$ century (for example, Defourny, 2004) and evidence across a range of European countries is reported to suggest an "upsurge" in social enterprise activity in the early $21^{\text {st }}$ century (Galera and Borzaga, 2009). Whilst the extent and definition of social enterprises might be contestable (Teasdale, Lyon and Baldock, 2013), it is clear that social enterprise activities did not appear overnight and the roots go much further back than some growth narratives might suggest (Teasdale, 2010; Nicholls et al., 2015). Greater emphasis on social responsibilities in the private sector and a trend towards increased outsourcing of public services into the private and social sectors (Kay et al., 2016) has highlighted that the boundaries between first (private), second (public) and third (social) sectors (Pearce, 2003) are blurred and organisations may have a combination of private, public or social objectives. This blurring of boundaries is not new and the existence of social enterprise type activities did not suddenly appear with the rise in use of the term social enterprise (Teasdale, 2010). Social enterprises are organisations employing enterprising methods to fulfil a social purpose (Dey and Teasdale, 2013; Peattie and Morley, 2008) specifically defined as autonomous organisations set up 
purposely for a clear social mission that generate their income through trade and reinvest the majority of their profits (SEJ, 2017; Social Enterprise UK, 2017). It would be surprising if organisations fitting that description had not existed previously, albeit with a different label. Teasdale (2010) highlights that the Salvation Army selling the War Cry from 1879 was an early example of a social enterprise type activity. However, with a few notable exceptions (e.g. Nicholls et al., 2015), there has been little examination of the historical foundations of social enterprise.

Even within its relatively short lifespan, the term social enterprise has been used in a variety of ways, by politicians, practitioners and academics, often based on a particular ideology (Kay et al., 2016). By highlighting earlier descriptions of social enterprise type activities within an historical context (Boddice, 2011), we cast light on social enterprise's present meaning and issues (Gray, 1905: vi). We will examine exemplars of practice (Boddice, 2011) to consider how they have been variously interpreted, focusing specifically on welfare provision activities that align with current definitions of social enterprise.

As the term social enterprise was not coined in earlier centuries, we examined histories of charity and philanthropy. Charities are organisations set up for a charitable purpose and must be for public not personal benefit (Charity Commission, 2017). Social enterprises might be charities, distinguished from other charities by the majority of their income being through trade and profits being reinvested. Philanthropy etymologically means the love of humanity but is commonly defined as actions that aim to promote the welfare of others, including charitable actions, giving and endowments. Philanthropy therefore is the broadest category, charity is an element of philanthropy and social 
enterprise is a particular type of organisation that might also be a charity (Teasdale, 2010). We therefore sought histories of philanthropy and of charitable service to identify whether there were examples of activity or organisations that met our definition of social enterprise. We focused specifically on charitable organisations that were concerned with human welfare.

A historical approach provides deep insights (McGowan and Westley, 2015) and can highlight trends and explain events within context (Byrne and Callaghan, 1998). Our historiographical review provides insights into prevailing themes that are recognisable in the context of $21^{\text {st }}$ Century social enterprises. We note histories emphasise a "higher" class that aims to improve those in the poorer classes, but not beyond their appropriate station. Attitudes towards the poor demarcated them into "deserving" and "undeserving" of assistance. Whilst there is a degree of voluntarism on the part of recipients of non-state welfare (Dodenhoff, 1988) the histories provide many examples that indicate a social control intent of founders of social enterprise experiments. Histories indicate that many social enterprise type activities were dependent on the entrepreneurial verve of key individuals and did not continue beyond the involvement of those social entrepreneurs. Key texts reveal that the political environment was an important influence on the development of social enterprise type activities and many social entrepreneurs were also politically active.

\section{Method, Focus and Boundaries}

Social enterprise was examined in its historical context (Boddice, 2011; McGowan and Westley (2015) by identifying key texts that examined philanthropy or charity during the 
$17^{\text {th }}, 18^{\text {th }}$ and $19^{\text {th }}$ Centuries (Gray, 1905; Jordan, 1959; Owen, 1965; Fraser, 1973;

Checkland, 1980; Cunningham and Innes, 1998; Gorsky, 1999). The histories were

written across the $20^{\text {th }}$ Century and provided perspectives up to the point where social enterprise was materialising as a concept.

As a full historical overview is beyond the scope of a journal article, we examined exemplars of practice (Boddice, 2011). Examples of welfare provision were explored in detail where they suggested evidence of social enterprise models of working and met the definition of social enterprise specified in our introduction. The historical texts shed light on the contextual setting within which these developments were undertaken and the varying perspectives of different writers in the $20^{\text {th }}$ Century. The history of wider voluntary and charitable activity is relevant to the development of social enterprise; histories of charitable and voluntary endeavour that make no mention of enterprising models as organisation form or activity (for example, Morris, 1990) could be providing a partial account.

Our review examined the period 1600 to 1908 because the Poor Relief Act 1601 was a step change in welfare provision, shifting responsibility from individual and church towards the state. Similarly, in 1908, the Old Age Pensions Act, was a pivotal point from the perspective of welfare provision, described as making the third sector the "Junior Partner in the Welfare Firm" (Owen, 1965: 526), as third sector service delivery shifted to increasing contractual partnerships with the state.

As a modern concept, social enterprise has not been specifically referred to within historical texts and it is by a process of interpretation of charitable delivery models from these texts that examples of activity that met our definition of social enterprises were 
gleaned. Instances of trading and business models of welfare provision by third sector organisations ${ }^{1}$ were identified in various periods. Teasdale (2010) empirically identifies six types of social enterprise organisation: revenue generator/awareness raising; contracted service provider; accommodation providers; participation based community; employment provider; training and work experience. Most of the historical social enterprise type models we identified focused on work integration i.e. employment, training and work experience. Other historical forms of social enterprise type activities included delivering State services under contract, micro-finance with social aims and fair trade.

Examples of the first quasi-social enterprises appeared in histories from the 1660s, some years after the passing of the Poor Laws, shortly after the English Civil War and concurrent with the Plague epidemic. These periods are examined in chronological order followed by discussion and conclusions. An overview of concurrent social and political trends allowed relevant themes to be identified. Findings from this historical review aimed to inform a better understanding of $21^{\text {st }}$ Century practices and attitudes and provide pointers for future investigations.

\section{Key Texts}

Many of the classic reviews of philanthropy or charitable service (Gray, 1905; Jordan, 1959; Owen, 1965) have been critiqued for progressive or evolutionary narratives, describing developments in welfare provision most often as a progression towards an ideal (welfare) state (Gorsky, 1999). Recent texts highlight the blurring of boundaries between sectors (Kay et al., 2016) and the 'moving frontier' of welfare provision (Finlayson, 1994) indicating that the balance between state, private and voluntarism in

\footnotetext{
${ }^{1}$ Referred to in the text as "quasi-social enterprises".
} 
providing welfare is ever changing rather than progressing along some evolutionary path. In this section we provide insights into the key texts and the perspectives of their authors, relative to current issues and themes in social enterprise.

Gray's (1905) history has been presented as an early example of a progressive narrative, from endowed charity through voluntarism to increased state welfare (Gorsky, 1999). Gray aimed to examine the meaning and worth of philanthropy focusing on the $17^{\text {th }}$ and $18^{\text {th }}$ Centuries and stated that his main purpose was description of the history. He concluded that philanthropy had been unsuccessful in alleviating poverty which was a normal incident of society caused by the industrial system and the "economic structure of society" (p.283). Gray welcomed increasing state intervention concluding that "the spectre of destitution, both physical and mental, could not be denied, and would not be exorcised by the feeble conjuring of philanthropy" (1905: 285). Gray highlighted the dichotomisation of philanthropist and beneficiary stating "Sense of failure had not yet taught the philanthropists humility. They still regarded themselves as being of another order from the poor; they were still scarcely conscious that 'God and their superiors' was a very composite expression" (1905: 291).

Jordan (1959) examined philanthropy in England from 1480 to 1660 and documented the rise of charitable trusts. Jordan's perspective is indicated by the opening lines of his text "This study is concerned with men's aspirations for their own age and generations yet to come... heroic effort to shape the course of history by creating enduring social institutions... determining the structure and nature of society..." (Jordan, 1959: 15). Jordan's method is worth noting: he examined the final wills of men to identify charitable donations, as well as attempting to identify all charitable donations in their lifetimes, across two centuries and ten English counties. The merchants and the gentry are heroes in Jordan's account, which does not lack hyperbole: "the merchants and the gentry were with an immense generosity and a sureness of aspiration establishing social and cultural institutions, a whole pattern of civilisation, all over England long before other and more reluctant classes of men made grudging concession that the mediaeval world was at an end." (Jordan, 1959: 19). Jordan's representation of the actions of a "powerful and responsible gentry" and merchants as being "heroic" is not dissimilar to heroic representations of social entrepreneurs in more recent times (see 
Parkinson and Howorth, 2008). Entrepreneurship features strongly in Jordan's account as he describes the charitable efforts of the "rising mercantile aristocracy" and "daring landed entrepreneurs" (Jordan, 1959: 19). Jordan highlights that religion, in this context Christianity, is inseparable from charitable endeavours and "great and angry preachers" were social reformers described as "naïve... warm and generous... these remarkable, these attractive, and these somewhat dangerous men" (p.160). Despite his opening statement, Jordan does examine women's role in charity, providing an admiring account of Queen Elizabeth I, and statistics that show women were independently active philanthropically.

Owen (1965) provides a detailed empirical account of "the benefactions of Englishmen which went to create and support a network of services for the mitigation of poverty, disease, infirmity and ignorance" (p.1) in his classic work English Philanthropy 1660-1960. Gorsky (1999: 3) suggests that Owen presents the $19^{\text {th }}$ Century in particular as "heroic days" of philanthropy. Owen's framing of charitable endeavour as "philanthropic" highlights the gatekeeping function of wealthy donors and their overwhelmingly moralistic views of the worthiness or otherwise of particular groups of beneficiaries.

Gray, Jordan and Owen all describe ups and downs in the extent of philanthropy but the underpinning tenet is a progressive account. In contrast, Fraser (1973) talks about the evolution of the British Welfare State as a 'an erratic and pragmatic response of government and people to the practical individual and community problems of an industrialised society' (p.1). The empirical material in Checkland's (1980) history of philanthropy in Victorian Scotland goes beyond the scope of our study of English philanthropy but is interesting in continuing the narrative that "philanthropists indeed helped to bring the state into action" (p.1). Checkland identifies three phases in the $19^{\text {th }}$ Century: individual philanthropic efforts (exclusively of upper and middle classes); organised corporate charities; and socialist pressures leading to state intervention. Her text is not chronological but themed according to objectives and functions. Checkland distinguishes between philanthropists who were activists and the majority, who were ritual givers and played a supporting role. 
Cunningham and Innes (1998) provide an edited volume of historical examinations of charity and philanthropy from the $17^{\text {th }}$ to $19^{\text {th }}$ Centuries. Of particular interest, Roberts (1998) examines voluntary associations and charity organization from 1700 to 1850 , with an emphasis on management.

The following sections draw on these key texts and other writers to provide an insight into enterprising methods of philanthropy that might be classified as quasi-social enterprises.

\section{Welfare Provision Pre-1660}

This section provides insight into the development of attitudes that prevail in later periods. Prior to 1660, in England poor relief was administered by either the monasteries, through church tithes, or local landholders (Jordan, 1959). Such provision might be classified as charitable, but for agricultural landlords it was motivated by their business needs. Landholders are believed to have seen such provision of welfare as necessary to supply labour for busy periods, such as harvest, and might struggle to recruit if they did not make provisions that made it advantageous for labourers to remain in the district (Van Leeuwen, 1994). "In slack periods it might be rational for employers to assist workers, ensuring their availability at times when demand for labour was high." (Van Leeuwen, 1994: 152).

During this period, however, the gradual erosion of traditional rural societal relationships through enclosures and clearances (the so-called Agrarian Revolution) led to a large number of people becoming unemployed and destitute throughout the UK (Owen, 1965). The reaction to this breakdown in traditional forms of welfare was the first legislative response of the State to problems of poverty and formed the basis of the Poor Laws of 1597 and 1601 and the Charity Law of 1597, which demarcated State 
responsibility to provide through local taxation for those unable to help themselves and (wealthy) people's voluntary duty to provide for all those the State did not assist. A system of "outdoor relief" provided paid employment through the parish system for those able to work (Jordan 1959). Solar (1995) suggests these combined provisions for poor relief played an important part in maintaining a stable political and social context. However, the English Civil War and subsequent overthrow of the British Monarchy in the 1640 s demonstrate questioning of social mores and traditions.

The dissolution of the monasteries and the establishment of the Anglican Church initiated a change in attitude towards the poor and welfare provision. The Anglican church, based on Puritan traditions, emphasised hard work and individual responsibility, an inevitable consequence placing responsibility for poverty on the individual rather than community or structure of society. Levy (1944) argues that it was attitudinal rather than structural problems that led to the inability of the old system to cope with these new problems. He refers to the growing stigma upon the nonpossessing class, their condition being held to be attributable to God's visible disfavour and their own inabilities; their thriftless, immoral and even deceitful habits of life...the general rule of all England was to whip and punish the wandering beggars (Levy, 1944: 135-6)

Owen contends that the enlargement of Christian evangelical notions, especially through the growing adoption of Puritan and protestant traditions, emphasised the social duties of the wealthy and the concept of "stewardship" rather than relief (Owen, 1965: 3). Bequests of alms, which were distributed to anyone in need as poor relief, were replaced by a new tradition of wealthy people making bequests and endowments under strict 
conditions, for the setting up of particular institutions and for specified groups of the poor. Conditions attached to such bequests might aim at individuals 'bettering themselves' and were developed to counter increasing threats of disorder.

This new model of philanthropy became a social norm: "The failure of a London merchant to settle some substantial and conspicuous charitable trust or gift was generally regarded as shocking” (Jordan, 1959: 143). By late $17^{\text {th }}$ Century, traditions of individual endowment further developed into "associated philanthropy" (Gray, 1905). Inspired by the development of joint stock trading companies, wealthy people pooled their resources to provide welfare and public services through the establishment of philanthropic associations of varying sizes and foci.

Threads from these shifts in attitude and changes in the structure of institutional welfare provision can be identified in later periods and it is within this context that the first quasi-social enterprises can be identified post-1660.

\section{First Social Enterprises 1660-1700}

As a result of the Plague (Black Death) epidemic of 1665, many wealthy families left London, resulting in large swathes of people becoming unemployed who had depended on the wealthy as employers. Thomas Firmin was the son of a Puritan minister who became the head of a philanthropic association with a range of wealthy donors (Gray, 1905; Sherwin, 1950; Owen, 1965). Firmin responded to the need by providing the unemployed poor with raw materials for "continuing their usual occupations" (Owen, 1965: 18). By the 1670's, Firmin had established a significant quasi-social enterprise employing 1700 spinners "in addition to flax-dressers, weavers and others" (Owen, 
1965: 19). Firmin's efforts mirror $21^{\text {st }}$ Century social enterprise activities in that an enterprising and income-generating organisation was set up with a primary social purpose and profits reinvested in achieving the social purpose.

Firmin is presented in detail in the histories, perhaps because original texts are available (e.g. Gentleman, 1698). At the same time, Thomas Gouge (a Presbyterian minister) also provided work for the unemployed in London (Gouge, 1856), suggested to be a precursor of Firmin's enterprise (Gray, 1905).

Historical accounts of this time highlight similarities with today's social enterprises: profit's role was to mitigate and make more efficient the input of charitable funds. Firmin is quoted as seeing "the loss of two pence in the shilling as money well spent" (Owen, 1965: 18). The founder's personal funds were intertwined with the social enterprise: Firmin "never considered his own private loss when it came into competition with a publick [sic] benefit" (Gentleman, 1869: 2). Owen (1965) suggests that Firmin's enterprise is of less interest to a history of philanthropy than his other charitable activities. And yet, the enterprise was of considerable size and larger than many present day social enterprises. Firmin was a leading figure in a range of related activities, including as a commissioner for "Briefs", which can be seen as an early form of charitable work under contract to the State, for a financial consideration. Commissioners for Briefs were authorised by the State to collect charitable contributions to a disaster relief fund from parish officials and ministers and were paid a percentage of what they collected (Owen, 1965: 24). Firmin belonged to a close network of Christian activists, with multiple links between himself and philanthropists such as Thomas Bray and Thomas Gouge. Gouge's work is suggested as a precursor to Firmin's enterprise (Gray, 


\footnotetext{
${ }^{2}$ Bray T. (1698) A General Plan of a Penitential Hospital for Employing and Reforming Lewd Women Publisher unknown, was an unrealised proposal for a social enterprise approach to relieving a specific disadvantaged group.

1905) but receives little attention in historical accounts. Firmin's enterprise was resourced through a joint stock principle of philanthropy but accounts tend to focus on the individual, echoing hyperbole in the eulogy (Gentleman, 1869: 6) which suggests "No Age and perhaps no Nation in the World has produced a man of a more useful... and extended charity."

In the same period, Thomas Bray, a founder of the Society for Promotion of Christian Knowledge (SPCK) developed a proposal for improving the situation of "Lewd Women" by taking them out of their "lewd" occupations into an institution that would provide alternative employment and training. Although this proposal did not proceed at the time, it can be seen as a precursor for much voluntary provision over the following 150 years, founded upon a missionary zeal for "improving" the lower classes. ${ }^{2}$ Firmin, Bray, Gouge and their contemporaries used their positions in the church and their influential networks, to speak out on behalf of the poor. Firmin is said to have been a "Hearty Assertor of Liberties" who "looked with Indignation and Contempt on those Citizens who, in a strain of Flattery... most humbly Addressed King Charles II that he would be graciously pleased to put Chains and Fetters on them, and thus prostituted those Rights and Immunities, which their Ancestors had taken such care to transmit safely to a most unworthy Generation. He thought that the perpetual bellowing of Passive Obedience, and Non-Resistance, from the Pulpits, did not a little contribute to fix these Slavish Impressions on People's minds." (Gentleman, 1698: 4 [sic]). 
These first quasi-social enterprises were all relatively short-lived and, like some modern social enterprises, they were very dependent on key individuals, early "social entrepreneurs," for their impetus and continuation. The examples provide early instances of organisations that were employing trading models and business practices to alleviate social need. Class divisions were extreme (Roberts, 1998) and lower classes were expected to be grateful for higher classes' interventions to improve their situation. The provision of social welfare through work, rather than direct donation was associated with a Puritan tradition of Protestant Christianity. Protestant and nonconformist traditions in the UK accepted the perfectability of man and emphasised self-improvement through personal effort (Robertson, 2016). The examples indicate that religiously motivated philanthropic associations employed methods familiar from individuals' business activities to find strategies and structured approaches to poverty and social problems.

\section{Effects of French and Industrial Revolutions}

The effects of both the Industrial and French (1789-1799) revolutions on the perception of and the need for charity cannot be overemphasized. Wealthy employers and landowners could no longer rely on "lower" classes being deferential (Hudson, 2001). Although the UK remained relatively unscathed by the French Revolution (Hobsbawm, 1962), European revolutionary fervour and the social upheavals during the Industrial Revolution instilled a growing fear of insurrection and of the mob which led: "not simply to a criminalisation of public demonstrations and even homelessness (in the Vagrancy Acts) but also a criminalisation of membership of associations of working people" (Hudson, 2001: 2). 
This context is important in understanding the charitable efforts of the period. The Industrial Revolution led to increasing urbanization and mobilization of the population. The late $18^{\text {th }}$ and early $19^{\text {th }}$ Centuries were also notable for exponential growth in the population of Britain (Williamson, 2002). The wealthy and the poor were cognitively and socially dissonant (Fraser, 1973). The fear that Hudson describes (above) compounded class divisions and antipathy. The criminalisation of homelessness and of associations of working people restricted the opportunity for groups of poorer people to be responsible for their own solutions. The 1834 Poor Law provided the barest minimum of support "assuming that more constructive assistance would be provided by voluntary charity. Charity, it was taken for granted, would carry the main burden of working class welfare, insofar as this was not handled by workers' self-help organisations. Those whose needs could not be met through self-help, mutual aid or charity must be prepared to face the rigours of the workhouse" (Owen, 1965: 136). Increasingly, the poor were bifurcated into those deserving and undeserving of support and punitive models of relief became normalized (Simons, 1955).

\section{The Deserving and Undeserving Poor}

Traditional almsgiving through the parish was viewed as encouraging mendacity and required a distinction between the "deserving" and "undeserving" poor. These concepts have dominated both the discourse and practice of welfare provision through to the modern day (Claeys 1994). The distinction between those who deserved and did not deserve charity is typified in Malthus' Essay on Population (1798), which has been described as a "thoroughgoing assault on the poor's right to charity” (Claeys, 1994: 
250). The deserving poor were considered appropriate recipients of charitable or philanthropic undertakings ("the silent and retiring sufferer labouring under unmerited difficulties" Malthus, in Simons 1955: 65), whilst the mendicant or undeserving poor ("the hopes of clamorous and obtrusive poverty with no other recommendation but rags" ibid p.98) would have to fall on Poor Law and the punitive workhouse, as provision of last resort. Bifurcations of the deserving and undeserving were evident in earlier accounts: endowments sought to differentiate between the "worthy poor and those who were believed to be either vicious or incorrigibly lazy" (Jordan, 1959: 41).

Thus, charitable efforts and poor relief in the late $18^{\text {th }}$ and early $19^{\text {th }}$ Centuries operated within a context of a religiously motivated concern for both spiritual and physical welfare, growing fear of insurrection by the urban poor, and distinctions between deserving and undeserving poor. Some believed that there should be limitations on any form of relief that might encourage the labouring classes wishing to rise above their station or social class or encourage mendacity. Hannah More's principles of education are perhaps exemplary of the prevailing attitude of the time "My plan for instructing the poor is very limited and strict. They learn of week-days such coarse works as may fit them for servants. I allow no writing." (Jones 1952: 92). Hannah and Martha More founded industry schools throughout the Mendips, with financial support from associates including Wilberforce (Gorsky, 1999).

At the same time, an alternative view began to emerge. The first systematic investigations of the newly urbanised poor recognised structural, as well as individual causes of endemic poverty. Sir Frederick Morton Eden (Winch, 1983: 515) proposed ongoing state involvement in alleviating poverty. Patrick Colquhoun in his Treatise on 
Indigence also saw an increased role for State provision (Bloom 2003), highlighting the "meager achievements of a century of charitable effort" (Owen, 1965: 101 [sic]).

Despite his radical ideas, Colquhoun conformed to the belief that different classes should remain in their place, stating that education of poor children should exclude anything "that shall pass the bounds of their condition in society...To exceed that point would be utopian, impolitic, and dangerous, since it would confound the ranks of society, upon which the happiness of the lower orders, no less than that in more elevated stations, depends" (in Owen, 1965: 101).

Despite the challenges and social attitudes of the $18^{\text {th }}$ and $19^{\text {th }}$ Centuries some social enterprise type activities were apparent.

\section{Late $18^{\text {th }}$ and early $19^{\text {th }}$ Century Quasi-social Enterprise}

The School for the Indigent ${ }^{3}$ Blind, formed in 1790 in Liverpool was one of the earliest examples of a quasi-social enterprise model within education, providing employment training in spinning, basket weaving and music, and employment opportunities for beneficiaries. Profits from the efforts of pupils were re-invested to fund the School. Similar schools followed, organised as private ventures fitting a quasi-social enterprise model, including the Asylum for the Industrious Blind in Edinburgh in 1793 and schools for the "Indigent Blind" in London and Norwich. The model is of extreme paternalism, of education for moral improvement, providing vocational training and employment but usually no other education. Schools based on this model opened across Britain for a variety of specific beneficiaries e.g. deaf, dumb, physically disabled. Long-term success

\footnotetext{
${ }^{3}$ i.e. poor or needy
} 
was however limited as many beneficiaries failed to get employment and resorted to begging (Gillard, 2011).

The Society for Bettering the Condition and Increasing the Comforts of the Poor (SBCP), founded in 1796 by Thomas Bernard, William Wilberforce and others provided perhaps the first recorded instance of the introduction of "scientific" and industrial methods to the provision of welfare and public service to the "inferior" classes. The SBCP's reports published from 1797-1817 present business practices introduced to a range of charitable organizations in the form of clearly formulated accounts, governance systems and the provision of information and evidence on poverty and its effective amelioration. SBCP reports highlight the growth in "schools of industry" which provided training in, for example, gardening, shoe-making, carding wool and for the girls "domestic economy" (Hadow, 1926:9 in Gillard 2011) including those founded by the More sisters in the Mendips (Gray, 1905; Gorsky, 1999).

Arising out of this movement, the Philanthropic Society (later to become the Royal Philanthropic Society) established a rehabilitation school in 1802 for children of criminals or children themselves convicted of a crime. It was known as the "Manufactory" as the children were engaged in manufacturing clothes, shoes and rope, profits from the sale of which were reinvested into the running of the reform school. This was an early example of a charity providing a service to the State under contract. It was very unusual for a charity of the time in that the rehabilitation school was a sentencing tool of the State's judicial system and the charity received payments from the State for providing this service - "an interesting early example of a voluntary organisation receiving government support for performing what were essentially public police 
functions." (Owen, 1965: 120). Subsequently, in 1849, the Philanthropic Society founded Redhill Farm to provide a self-supporting, income-generating farm for delinquent boys.

By the time Mary Carpenter made her observations in 1853, she could note Ragged Schools, Industrial Schools and Reform Schools all “managed by voluntary bodies and financed by private contributions, payments by parents, and grants from the State." (Levin, 1940, p42). Ragged schools provided free education for the "raggedy children" of the poor, teaching industrial and commercial skills, basic literacy, numeracy and Bible studies. Industrial schools had two main objects, to instil in the children the habit of working and to develop the latent potential of the destitute child (Gear, 1999). The Ragged School movement also spawned further quasi-social enterprise experiments, incorporating adult industrial and commercial education, credit unions and income generating coffee shops/reading rooms (Infed. 2008). As in earlier centuries, the social reformers at the heart of quasi-social enterprise experiments, were an interwoven overlapping network. Lord Shaftesbury was the first Chairman of the Ragged Schools' Union. He employed two redundant warships to house up to 400 boys on the Thames, training them in seamanship skills ready for employment in the merchant navy, as well as funding refuges in central London for boys and girls, teaching carpentry, cobbling and tailoring in addition to seamanship skills, and domestic service skills to the girls (Wolffe, 2004).

The first recorded evidence of formal micro-finance in Britain appeared in this period: the Bath Society for the Suppression of Common Vagrants and Impostors, Relief of Occasional Distress and Encouragement of Industry, was launched at the end of the 
$18^{\text {th }}$ Century. Under their scheme, loans for tools and occasionally for cash-flow were made to those who had become unemployed so that they could continue to provide income for their families (Owen, 1965: 111).

Philanthropic efforts in this era were not without their critics and Thomas Carlyle referred to the "universal syllabub of philanthropic twaddle" (Carlyle, 1850). A pervasive theme was the improvement of the poor under the direction and control of the upper classes, but even leading social reformers stopped short of enabling the poor to rise above their station. The following section examines quasi-social enterprise activity that was bottom-up rather than imposed by "higher" classes.

\section{Working Class Associations}

Although the new "working class" of the late $18^{\text {th }}$ and early $19^{\text {th }}$ Centuries consisted of heterogeneous groups (e.g. artisans, factory workers, day-rate labourers), Thompson (1968) argued that they shared social and political concerns which led to a general pressure for suffrage and employment contracts. The gradual achievement of increased rights enabled the working classes to plan and provide for their own welfare for the first time. The Friendly Societies Act of 1793 was the first acknowledgement of the growth of this phenomenon (Gorsky, 1998), although Trade Unions and other forms of association were actively discouraged or banned (Hudson 2001). Class division and fear of insurrection was, no doubt, behind a widespread antagonism towards working class associations among the ruling classes. Even important social reformers, including Lord Shaftesbury, rarely supported the rights of workers to form unions and associations. 
The (failed) revolutions across the rest of Europe in 1848 and the fear of revolution in the UK (Hobsbawm 1962) led to increased pressure from the middle and upper classes to impose State control upon these associations. The first Register of Friendly Societies was set up in 1846 (Gorsky, 1998) and the first Industrial and Provident Societies Act (IPSA) was introduced in 1852 "whereas various Associations of Working Men have been formed for the mutual Relief, Maintenance, Education and Endowment of the Members, their Husbands, Wives, Children, or Kindred, and for procuring to them Food, Lodging, Clothing, and other Necessaries, by exercising or carrying on in common their respective Trades or Handicrafts" (From the 1852 Act, in Hudson, 2001, p7). Industrial and Provident Societies retained profits (and losses) as the common property of members.

Despite the initial illegality of working class association, an ability and desire of workers to organise led to the first flowerings of the $19^{\text {th }}$ Century self-help movement (Hudson, 2001: 3-4; Gorsky, 1998). The $19^{\text {th }}$ Century saw the flowering of the Chartist Land Movement, a quasi-social enterprise scheme to provide income generating, selfsupporting small holding communities for working class families (Chase, 2003; Cole, 1944). Other initiatives, such as the Co-operative experiments of the Fenwick Weavers and the Rochdale Pioneers, whilst set up for similar social reasons, moved quickly towards the trade union and Friendly Societies' model (Gorsky, 1998, Cole 1944) and became most concerned with provision for members rather than any wider public benefit (Potter 1891, Cole 1944). 
Industrial and Provident Societies for Members Benefit, whilst falling outside the remit of this study, included Co-operatives, Credit Unions and Friendly Societies ${ }^{4}$. The alternative, and more relevant, form of Industrial and Provident Society was for Community Benefit, by which an association could be legally recognised and engaged in business and trading activities, where the purpose of these activities could be demonstrated to be for the benefit of the community. This structure could be the first instance of social enterprise recognised by the State and provide an early recorded instance of working class association, rather than the philanthropy of the wealthy, as a method for delivering social welfare for the wider community. Evidence for the purpose and undertakings of these first Industrial and Provident Societies for Community Benefit remains scant and warrants further detailed investigation.

\section{Quasi-Social Enterprise in Housing Provision}

The growth of railways and urban improvements, coupled with moves such as the Metropolitan Management Act of 1855, which encouraged Local Authorities to improve infrastructure of growing cities and for the first time allowed compulsory purchase, resulted in many slum dwellers being dispossessed (Owen, 1965). William Booth, founder of the Salvation Army, provides a model of a work focussed quasi-social enterprise approach to the growing problems of urban housing provision. Due to financial constraints, the Hanbury Street cottage for fallen women in London was set up to become self-supporting as quickly as possible: those who received assistance learned to pay their

\footnotetext{
${ }^{4}$ Similarly, it has been suggested that the Guild model provides examples of early quasi-social enterprise practice from as early as the $9^{\text {th }}$ Century (Defourny et al, 1999; Larner et al., 2017) but they existed in all of their various forms for the benefit of their members, rather than the wider community, and are therefore not addressed in this paper.
} 
way (Whelan 1996) following the "elevator" principle, by which beneficiaries received vocational and moral training and paid their way by stages, receiving progressively better living conditions in return (Railton, 1912). By 1894, this scheme had become widespread within Salvation Army provision and over 1000 people were employed within such vocational schemes (Whelan, 1996). Booth and the Salvation Army were widely criticised for not distinguishing between worthy and unworthy recipients of assistance, and deemed to be overly sentimental and irresponsible (Owen, 1965; Whelan, 1996).

Other social housing projects followed business models, for example the Society for Improving the Condition of the Labouring Classes built dwellings with the intention of providing good quality social housing at affordable rents. The novelty of this model, was that investors in these schemes received a return on their investments (usually capped at 5\%). It is worth noting that in its first meeting, the Society argued that "unless charity softened the acerbities of the New Poor Law, the tensions in English Society might become insupportable" (Owen 1965: 375); this model meant a viable, if capped, return on money, it met social criteria for good works, reduced class tensions and subsequently spread widely. Individual wealthy philanthropists, including Angela Burdett-Coutts, Sydney Waterlow, and the Guinness family, along with philanthropic associations such as the Peabody Trust, all invested in similar schemes.

The philanthropic work of George Cadbury, who also worked with this semicommercial model of housing provision, sits quite differently within a social enterprise history. Whilst many of his compatriots also developed model villages and other relief measures tied to gainful employment (for example, Salt and Rowntree), in Cadbury's case the development of Bourneville was not just for his own workers, but for workers 
from across the district. Cadbury also ensured that any resulting profits were re-invested in further philanthropic works (Gardiner, 1923).

\section{Late $19^{\text {th }}$ and Early $20^{\text {th }}$ Century Developments}

The late $19^{\text {th }}$ and early $20^{\text {th }}$ Centuries provide further evidence of quasi-social enterprise activities. Working class associations moved towards mutual assistance on increasingly socialist models, through trades unions and co-operatives, rather than wider community benefit models, exemplified by the formation in 1872 of the national Co-operative Wholesale Society (Potter 1891; Cole 1944). Christian and religious-inspired groups continued to use social enterprise models as part of their welfare provision. Social enterprise models were also used to affect change in business and legislative practice. A notable case, and a precursor of modern fair trade practice, was the introduction by Booth of new production methods for matches in 1891. His Salvation Army set up a factory specifically as part of a campaign to eliminate the use of yellow phosphorous for match production, replacing it with less harmful red phosphorous. Although this raised the price of a box from $2 \frac{1}{2} \mathrm{~d}$ to $4 \mathrm{~d}$ he found people were willing to pay the premium. As part of his campaign to ban the use of yellow phosphorous, Booth encouraged legislators to visit the houses of factory workers, where they would darken the rooms. The workers skin could be seen to glow from within as a result of the poisoning (Whelan 1996: 39). In 1901, major match manufacturer Bryant and May switched to red phosphorous and in 1908 legislation banned yellow phosphorous (Railton, 1912).

Widening of suffrage (Hudson 2001), from the 1890s, resulted in increasing pressure for State old age pensions and other social legislation, culminating in the Old 


\begin{abstract}
Age Pensions Act of 1908 (Owen, 1965, p526). Whilst not fully establishing a welfare state this act can be a seen as a pivotal point from the perspective of third sector welfare provision overall.
\end{abstract}

\title{
Discussion
}

Reviewing histories of charity and philanthropy identified social enterprise type models of welfare relief during $17^{\text {th }}, 18^{\text {th }}$ and $19^{\text {th }}$ Century England. In discussing pervasive issues, we challenge social enterprises and researchers to consider the implications for their own approaches and practice.

Within current English public policy, social enterprise occupies a particular place: as a provider of public service within a system of welfare pluralism; as a method of relieving dependence on grant aid for non-profit organisations, and as a medium for the introduction of business models of operation and organisation into a field traditionally dominated by voluntary association (Teasdale, 2010). Managerial and functionalist accounts portray social enterprise as an inevitable and desirable response to State failure. Just as early historians tended to present an evolutionary progression towards State welfare systems, we are provided a progressive account of moves towards something more desirable, (e.g. Pearce, 2003; Leadbeater, 2007). Critical perspectives question this view and suggest that modern social enterprise represents a shift towards market dogmatisation (Dey and Teasdale, 2013); a deeply political undertaking that is difficult to separate from its political context. Later historians were critical of progressive accounts. This review noted an ebb and flow to social enterprise activities, dependent on changes in welfare provision and religious and political imperatives of the day. 
The historiography indicates that, where the State and charitable provision adequately provided welfare and poor relief, for example through the paternalistic philanthropy of the wealthy and old Poor Law provision in Tudor and early Stuart England, through associated philanthropy in the early $17^{\text {th }}$ century or through the expanding Welfare State in the early $20^{\text {th }}$, historians provided fewer examples of social enterprise models. Where these systems broke down, models of charitable poor relief or welfare provision included more quasi-social enterprises. During the $17^{\text {th }}$ Century, quasi-social enterprises were included almost experimentally within a movement towards associated philanthropy, as attempts to find strategies and structured approaches to poverty and social problems that met both perceived social need and the desired religiously inspired moral improvements in beneficiaries. Examples indicate social purpose organisations employing trading models and business practices and providing services under contract for the State. Joint stock trading provided the model for resourcing and organising philanthropic associations.

Increased urbanisation in the late $18^{\text {th }}$ and early $19^{\text {th }}$ Centuries was presented as a problem that provided a context for social reform based on Christian concerns for spiritual and physical welfare, fear of insurrection by the urban poor, and distinctions between deserving and undeserving poor. Class divisions were emphasised and the poorer classes were expected to be appreciative of the upper classes' interventions to improve their situation. Clearly, this is not a new phenomenon as highlighted by Thucydides (c420-415 BC): “The strong do what they have the power to do and the weak accept what they have to accept," but the disparity in power was an unchallenged norm in many of the histories. Members of the wealthy class would do unto the poor what they 
believed to be needed, mainly through the provision of "improving" work, separating out those deserving from those undeserving of assistance. The challenge to social enterprises today is to consider whether threads of this attitude likely still prevail, possibly as invisible or unchallenged assumptions.

Certainly, social enterprise activities were instigated by more powerful wealthy individuals, who had access to resources through their networks of wealthy friends and family. They were significantly better educated than the beneficiaries of their efforts and it is interesting to consider whether that is mirrored by a similar intelligentsia today, who access resources through their networks of government agencies and corporate connections, who understand "the system" and are, therefore, better able to set up social enterprises, have careers in the social enterprise sector, and decide which groups or individuals are most deserving of their efforts.

It was not until the $19^{\text {th }}$ Century that any significant movements in self-help organisations were identified, when increased rights enabled the working classes to organise their own welfare. Although the Friendly Societies Act was introduced in 1793, trade unions and other forms of working class associations were actively discouraged or banned, in part due to class division and fear of insurrection. Harris (2005), argues that it was the introduction and financial and material impact of such changes as the 1834 Poor Laws that accelerated radical experiments in working class association. In the late 19th Century, working class associations and self-help organisations were much more widespread, along with the continuing involvement of the upper classes in paternalistic, philanthropic work in general and in quasi-social enterprise in particular. 
There is limited evidence of overall effectiveness of social enterprise as a method of providing relief. Like some modern social enterprises, specific endeavours like Booth's match factory in the $19^{\text {th }}$ Century, were feted for their successes and continue to be well known today. However, just as today, there were varying opinions on how success should be measured. Elizabeth Macadam (1934), commenting on the semicommercial housing programmes of the late $19^{\text {th }}$ and early $20^{\text {th }}$ centuries, found that these schemes were too small to impact on the growing problem of homelessness and poor housing and both "signally failed either to do the job itself or to stimulate the State to do it adequately" and "tended to obscure the magnitude of the real problem by a false sense of achievement" ( $\mathrm{p}$ 138-39). Such attitudes judged the impact of these schemes on society as a whole. Whelan (1996), conversely, argued that schemes that encouraged poor people to engage in employment and thus improved their moral characters were worthwhile in themselves, seemingly more concerned with saving individual souls than with the overall impact on society.

\section{Conclusion}

In conclusion, this paper highlights the importance of considering the social, political and historical context of social enterprises to understand trends and provide authentic explanations. Some of the themes that the key texts recognised in centuries past, likely still prevail in social enterprises today, creating challenges and opportunities for researchers and practitioners. It was noted that social enterprise models occurred most frequently when other systems of welfare break down. It is only by examining histories 
that we are able to identify such trends: cross-sectional studies are very limited in the conclusions that can be drawn.

The discussion challenged current social enterprise practitioners and researchers to consider whether elements of a higher class with power over beneficiaries persists today. It was suggested that in the $21^{\text {st }}$ Century, the higher class is more likely to be an intelligentsia with access to networks, resources and education that advantages them in founding and governing social enterprises. Clearly this has implications for access and exclusion.

It was striking that social enterprise models were closely associated with the Puritan view of poverty which distinguished between those "deserving" and "undeserving" of assistance. Whilst we might baulk at such a bifurcation of the population, we should question whether elements persist and particular groups or individuals are viewed as more and less deserving of assistance, and be mindful of the implications.

The reviewed histories were explicit about the religious affiliations of individuals and groups, particularly highlighting the role of Christian philanthropists. There were few examples of non-Christian affiliations among the proponents. Studies of $21^{\text {st }}$ Century social enterprises are often silent on religious affiliation, which might in part be due to a more secular society and individuals being less open about their beliefs. We would challenge researchers to interrogate religious affiliations more closely and to ask questions about beliefs. The histories suggested that religion was important for social enterprise and philanthropy as a motivator for action and inclination towards specific types of action but also importantly, in determining approaches, models and attitudes. 
The histories present accounts that are heroic and venerate the same key individuals: while networks were often acknowledged as important, particularly by Gray (1905), theirs was very much a supporting role. Similar accounts are perceived today, with high-profile founders of social enterprises lionised and the contribution of those around them ignored or at best tokenised. A major limitation of historical approaches is that they are restricted to accounts of those for whom records exist. We do not suffer the same restriction. Researchers can ensure that they provide a full and rounded picture by not focusing solely on the high profile leaders of social enterprises and instead collecting data that are more representative of the variety of perspectives.

The historiography covered three Centuries and therefore was limited in the level of depth that could be applied to each example. We also did not go beyond 1908 which was a watershed in the emergence of the Welfare State. Investigation into the emergence of modern trends of social enterprise activity from 1908 to the present day would allow the themes identified in our study to be examined further. Most of the social enterprise type activities that we identified in historical accounts were related to employment, education and training. This is partially explained by our focus on welfare, but also by the historical context. Further research is required to uncover other possible types of social enterprise activities. Examination of the historical roots of social enterprises is very relevant to $21^{\text {st }}$ Century social enterprises and this paper has shown that history can identify opportunities and challenges for researchers and practitioners. 


\section{References}

Bloom M. (2003), "Editorial - primary prevention and the causes of poverty: An historical note on Patrick Colquhoun at the beginning of the 19th Century," Journal of Primary Prevention, 24, (2).

Boddice, R. (2011), "Forgotten antecedents: entrepreneurship, ideology and history" in Ziegler, R., (ed). An Introduction to Social Entrepreneurship. Edward Elgar Publishing. Cheltenham.

Byrne, D.S. and Callaghan G. (1998), Complexity Theory and the Social Sciences: the State of the Art. Routledge, London.

Carlyle, T. (1850) "Latter Day Pamphlets" Victorian Web at www.victorianweb.org [accessed $17 / 3 / 17]$.

Charity Commission (2017), What Makes a Charity. Charities Commission England and Wales at https://www.gov.uk/government/publications/what-makes-a-charity-cc4/whatmakes-a-charity-cc4 [accessed 12/10/17].

Chase M. (2003), "Wholesome object lessons: The Chartist land plan in retrospect" English Historical Review, Vol. 118, p.475.

Checkland O. (1980), Philanthropy in Victorian Scotland: Social Welfare And The Voluntary Principle, John Macdonald Publishers, Edinburgh.

Claeys G. (1994), "The origins of the rights of labor: Republicanism, commerce, and the construction of modern social theory in Britain, 1796-1805" Journal of Modern History, Vol 66 (2) 249-290.

Cole, G.D.H., (1944) A Century of Co-operation Allen \& Unwin. Oxford.

Cunningham H. and Innes J. (eds) (1998) Charity, Philanthropy and Reform from the 1690s to 1850 Macmillan Press, Basingstoke.

Defourny J, Develtere P and Fontenau B. (1999) Social Economy: the Worldwide Making of a Third Sector EMES at https://emes.net/publications/other-texts/emes-selectedtexts/social-economy-the-worldwide-making-of-a-third-sector/ [accessed 12/11/16].

Defourny, J. (2004) Social Enterprise in an Enlarged Europe: Concept and Realities EMES at https://www.scribd.com/document/42022092/Defourny-J-2004-SocialEnterprise-in-a-Enlarged-Europe-Concepts-and-Realities [accessed 12/11/16].

Dey P. and Teasdale S. (2013) "Social enterprise and dis/identification" Administrative Theory \& Praxis Vol 35 (2) 248-270.

Dodenhoff D. (1988) “Is welfare really about social control?" Social Service Review Vol. 72 (3) $310-336$.

Finlayson G. (1994) Citizen, State, and Social Welfare in Britain 1830-1990 Clarendon Press, Oxford.

Fraser, D. (1973) The Evolution of the British Welfare State: A History of Social Policy since the Industrial Revolution. MacMillan Press Ltd, London. 
Galera G. and Borzaga C. (2009) "Social enterprise: An international overview of its conceptual evolution and legal implementation" Social Enterprise Journal, Vol 5 (3) 210-228.

Gardiner A. (1923) Life of George Cadbury, Allen and Unwin, London.

Gear G. L. (1999). Industrial Schools in England, 1857-1933; 'Moral Hospitals' Or 'Oppressive Institutions'? Unpublished PhD Thesis. University of London Institute of Education.

Gentleman, A. (1698) The Charitable Samaritan or a Short and Impartial Account of that Most Eminent, and Publick-Spirited (sic) Citizen, Mr Thomas Firmin. By A Gentleman of his Acquaintance. London.

Gillard, D. (2011) Education in England: the history of our schools. www.educationengland.org.uk/history. [accessed 17/3/17].

Gorsky M. (1998) "The growth and distribution of English friendly societies in the early nineteenth century" The Economic History Review, New Series, Vol. 51 (3) 489-511.

Gorsky, M. (1999) Patterns of Philanthropy: Charity and Society in Nineteenth Century Bristol. Royal Historical Society Studies in History. Boydell Press, Woodbridge.

Gouge T. (1856) Riches Increased By Giving To The Poor; On The Surest And Safest Way Of Thriving. Reprint. Partridge, London.

Gray, B. (1905) A History of English Philanthropy: From the Dissolution of the Monasteries to the Taking of the First Census. King \& Son, Westminster.

Harris B. (2005) "Health by association; a response" International Journal of Epidemiology Vol 34 (2) 488-490.

Hobsbawm E. (1962) The Age of Revolution: Europe 1789 to 1848, Abacus, London. Hudson A. (2001) Equities and Trusts Routledge, London.

Infed (2008) History of Lord Shaftesbury: www.infed.org/walking/wa-shaft.htm accessed $1 / 11 / 17]$.

Jones M. G. (1952) Hannah More Cambridge University Press, Cambridge.

Jordan, W. K. (1959) Philanthropy in England, 1480-1660: a study of the changing pattern of English social aspirations Allen \& Unwin, London.

Kay, A., Roy, M.J. and Donaldson, C. (2016) Reimagining social enterprise. Social Enterprise Journal, Vol. 12 (2) 217-234.

Larner, J. and Cheverst, K.W.J. (2017) "The open source guild: creating more sustainable enterprise" Journal of Management Development. 36 (1) 71-78.

Leadbeater C (2007) Social enterprise and social innovation: Strategies for the next ten years UK Cabinet Office, Office of the Third Sector, London.

Levin Y. (1940) "The Treatment of Juvenile Delinquency in England during the Early Nineteenth Century” Journal of Criminal Law and Criminology Vol. 31 (1) 38-54. 
Levy H. (1944) "The economic history of sickness and medical benefit since the puritan revolution" The Economic History Review, Vol 14 (2) 135-160.

Macadam E. (1934) The New Philanthropy: A Study of the Relations Between the Statutory and Voluntary Social Services. Allen and Unwin, London.

McGowan K. and Westley F. (2015) "At the root of change: the history of social innovation.” In: Nicholls A., Simon J., Gabriel M. (eds) New Frontiers in Social Innovation Research. Palgrave Macmillan, London.

Morris, R. (1990), 'Clubs, societies and associations', in F.M.L. Thompson, ed., The Cambridge social history of Britain 1750-1950. Volume 3. Social agencies and institutions, Cambridge University Press. Cambridge.

Nicholls A., Simon J., and Gabriel M. (2015) New Frontiers in Social Innovation Research. Palgrave Macmillan, London.

Owen, D. (1965) English Philanthropy 1660-1960. Harvard University Press, Cambridge, MA.

Parkinson, C. and Howorth, C. (2008). "The language of social entrepreneurs" Entrepreneurship and Regional Development 20 (3), 285-309.

Pearce, J. (2003) Social Enterprise in Anytown, Calouste Gulbenkian Foundation, London.

Peattie, K. and Morley, A. (2008), Social Enterprises: Diversity, Dynamics, Contexts and Contributions, Social Enterprise Coalition, Cardiff.

Potter B. (1891) The Co-operative Movement in Great Britain Allen \& Unwin, London.

Railton G.S. (1912) The Authoritative Life of General William Booth, Founder of The Salvation Army Salvation Army, London.

Robertson, R. (2016) "Enlightened piety during the age of benevolence: the Christian knowledge movement in the British Atlantic world" Church History, 85 (2).

Roberts M.J.D (1998) "Head versus heart? Voluntary associations and charity organizations in England, c.1700-1850" in H. Cunningham and J. Innes (eds) Charity, Philanthropy and Reform, Macmillan Press, Basingstoke.

SEJ (2017) Meet the New Editor of the Social Enterprise Journal, http://emeraldgrouppublishing.com/products/journals/journals.htm?id=sej [accessed 2/10/17].

Sherwin O. (1950) "Thomas Firmin: puritan precursor of WPA" Journal of Modern History, Vol. 22 (1) 38-41.

Simons R B (1955) “T. R. Malthus on British society” Journal of the History of Ideas, Vol. 16 (1) 60-75.

Social Enterprise UK (2017) What is it All About. Social Enterprise UK website: www.socialenterprise.org.uk/What-is-it-all-about [accessed 12/10/17].

Solar P. (1995) "Poor relief and English economic development before the Industrial Revolution" Economic History Review Vol. 48 (1) 1-22. 
Teasdale, S. (2010) "Models of social enterprise in the homelessness field" Social Enterprise Journal Vol. 6 (1) 23-34.

Teasdale, S., Lyon, F. and Baldock, R. (2013) "Playing with numbers: a methodological critique of the social enterprise growth myth" Journal of Social Entrepreneurship, Vol 4 (2) 113-131.

Thompson E. P. (1968) The Making of the English Working Class Second Edition, Pelican, London.

Thucydides (422-415BC) History of the Peloponnesian War, Book V.

Van Leeuwen M. (1994) "Logic of charity: poor relief in preindustrial Europe" Journal of Interdisciplinary History, Vol. 24 (4) 589-613.

Winch D. (1983) "Science and the legislator: Adam Smith and after" The Economic Journal, Vol. 93 (371) 501-520.

Williamson, J.G. (2002). Coping with City Growth during the British Industrial Revolution. Cambridge University Press, Cambridge.

Whelan R. (1996) The Corrosion of Charity: From Moral Renewal to Contract Culture Institute of Economic Affairs, London.

Wolffe J. (2004), Cooper, Anthony Ashley: Seventh Earl of Shaftesbury (1801-1885) Oxford Dictionary of National Biography, Oxford University Press, Oxford. 